In the Special Issue on Multicultural Social Justice Leadership Development Guest Editor: Carlos P. Zalaquett, University of South Florida

\title{
Multicultural Social Justice and Human Rights: Strategic Professional Development for Social Work and Counseling Practitioners
}

\author{
Jessica A. Barrett \\ Millersville University
}

\begin{abstract}
Social work and counseling practitioners routinely provide services to clients of diverse cultural backgrounds. Multidimensional issues related to human diversity, social justice and human rights often prevent practitioners from providing competent and effective services to all populations. It is vital that these professionals focus on individual leadership development from a multicultural social justice perspective. The concept of social justice challenges existing structures and when paired with the human rights paradigm can significantly impact competent and ethical service delivery and practice. A focus on professional development among students, new professionals, and experienced practitioners can aid individuals in implementing human rights and social justice strategies within individual practice, organizations and communities.
\end{abstract}

Keywords: social justice, multicultural competence, counseling, social work, diversity

\section{Reflections from the 2010 Multicultural Social Justice Leadership Development Academy}

Multidimensional issues related to diversity, social justice and human rights often challenge social work and counseling practitioners and students to provide competent and effective services and advocacy for vulnerable populations. As an MSW, immersion into the theoretical systems for service delivery in the classroom has enhanced my understanding of these challenges and made evident the vital need to focus on leadership development and strategic action opportunities for professionals. Within the Multicultural Social Justice Leadership 
Development Academy (MSJLDA), held in March 2010, I had the unique opportunity to further this concept both as a masters-level student and a conference co-coordinator as part of an academic internship.

Simultaneously, I had the opportunity to participate in an academic course focused on human rights and social development, which created a unique pairing of academia with the action oriented focus of the MSJLDA. Reflections from these events solidify the belief that the concept of social justice when paired with a human rights paradigm can create a powerful context for understanding that the denial of such justice is not simply an issue of competent and ethical service delivery, but of protecting basic human rights.

\section{Professional Standards and Human Rights}

To foster the importance of social justice leadership development as a teachable concept connected both to the classroom and professional service, it is important to draw on our ethical foundations. The National Association of Social Workers (NASW) Code of Ethics (1999) outline score values and ethical standards for social workers, including the vital importance of multicultural competence, advocacy, empowerment, and social justice. NASW additionally supports the Standards for Cultural Competence along with the indicators for the achievement of such standards (NASW, 2007). Counselors practice within similar ethical guidelines from the American Counseling Association (ACA) which augment the counseling mission to promote the quality of life, respect, diversity, and human dignity of all persons (ACA, 2005). Counseling professionals also support the Advocacy, LGBTQ, and Multicultural Competencies to address the need for client empowerment and self-advocacy within vulnerable populations.

In order to provide a broader scope of vision, social justice leadership should be fundamentally understood and related to human rights. The Universal Declaration of Human Rights (UDHR) provides this foundation and was drafted by the General Assembly of the United Nations more than 60 years ago in 1948. This document affirms the human dignity and worth of every person and these basic rights guarantee individual autonomy, full inclusion and participation in society, and the right to social development and higher standards of life and freedoms. As such, professionals must be taught to recognize human rights violations both abroad and within their own communities and areas of service.

Social work and counseling standards for professional practice support the basic human rights outlined in the UDHR and other international documents. Professionals in each area acknowledge that basic human rights and social justice are inherent within professional, as well as personal, values and ethics. These professional standards and the UDHR also recognize the importance of action steps and the need for substantial and measurable goals. A focus on professional leadership development among students, new professionals, and experienced practitioners can aid individuals in implementing human rights and social justice strategies within individual practice, organizations and communities. 


\section{Multicultural Social Justice Leadership Development Academy}

The triangulation of the UDHR, counseling and social work standards, and professional ethical guidelines, collectively lays the groundwork for understanding and fueling social justice advocacy and strategic action in professional practice. Unfortunately, the inherent relationship between social justice leadership, advocacy, and human rights is often not connected within daily practice activities.

Many of the individuals and groups that we serve lack the resources, support, and education to compete and elevate their social and economic status. We must therefore provide additional support from the broader society and the education, empowerment, and significant opportunities to have their voices heard on the local, national, and international stage. We must have the ability to aid these individuals and groups in finding this voice and can only do so through our own proper education and strategic leadership. The MSJLDA provides just such a supportive environment and an opportunity for safe, meaningful dialogue in which to move theoretical frameworks from the pages of publications to our daily professional practice. Leadership development therefore, is a vital component of one's professional education and provides an action-orientation from which to practice competently and promote proficient standards of social justice, human rights and advocacy.

The Multicultural Social Justice Leadership Development Academy (MSJLDA), held in March 2010, in Pittsburgh Pennsylvania, created a unique forum for practitioners to create these connections through multidisciplinary presentations and facilitated dialogue. Formal workshopstyle presentations were allotted 50 minutes for theoretical, research, and practical information, 25 minutes for participant discussion and questions and 15 minutes of presenter-facilitated discussion and creation of tangible action steps and strategies focused on leadership roles and individual efforts to create change within their profession and communities. The MSJLDA was purposefully designed with the following goals:

- Provide an opportunity for professionals from across the United States to participate in professional development activities designed to foster leadership potential and action strategies from a multicultural social justice perspective.

- Build unity among practitioners from diverse specialty areas.

- Provide a free conference, open to all professionals and thus address the economic barriers that many new professionals encounter, which prevents them from attending national conferences and accessing vital educational opportunities.

- Celebrate the impact of recent multicultural social justice advocacy and competency standards as positive paradigm shifts within the social work and counseling professions as part of the correlating national professional organizations (NASW and ACA).

Formal workshop-style presentations focused on building individual, and collective, leadership associated with multicultural social justice issues in relation to vulnerable populations and diverse areas of practice. This forum for interactive discussion created opportunities for participants and presenters to discuss and generate tangible action strategies to be implemented within individual practice areas, communities, and organizations. 


\section{MSJLDA Action Strategies and the UDHR}

The importance of strategic actions and the need for substantial and measurable goals cannot be underemphasized. The MSJLDA focus on leadership development provided participants the means to implement human rights and social justice strategies within their own communities. Action strategies and outcomes identified at the MSJLDA will benefit many vulnerable populations and should be directly linked to the UDHR.

Committees formed during the MSJLDA will focus on the implementation of agreed upon action strategies and the continual development of, and advocacy for, multicultural social justice in both local, national, and international communities and organizations. The following action strategies were identified by participants at the MSJLDA and should be guided by the basic tenants of the UDHR Articles and International Covenants on Civil and Political Rights and Economic, Social, and Cultural Rights. Committees will proceed with each action throughout the March 2010-2011 annual cycle and prepare reports and presentations for the 2011 conference. Each annual conference will build upon previous years and create a new generation of professional leaders and proponents of human rights to ensure that all people have the human right to self-determination and a higher quality of living.

The Committee on Implementing Social Justice Curriculum: Elementary, Middle, and High Schools:

- Incorporate practical information and topics into established educational curriculum ensuring that education goes beyond academics.

- Dialogue with students, parents, and school personnel to teach and educate around cultural differences and how cultural discriminations leads to unfair punishment of children of color.

- Develop an educational program for students and parents to be social justice advocates in schools and educational settings.

The Graduate Student Committee on Implementing Multicultural Student Learning:

- Encourage personal student growth within graduate programs through an increase in classroom and department activities in order to build more culturally competent professionals that will advocate for social justice.

- Incorporate and promote service learning projects to expand individual student perspectives and understanding of human rights issues within their own communities.

- Increase inter-university collaboration to develop meaningful service learning experiences for students and community members.

The Political Action Committee on Legislation and Communication with Local/State Politicians:

- Form relationships with local, state, and national legislators and advocate for the inclusion of public policy and legislative curriculum in all public education.

- Institutionalize a system of transparency within individual organizations in order to promote democracy: provide a venue for the unheard to speak. 
- Create greater awareness of the multicultural and social justice competencies within local organizations.

The Professional, Faculty, and School Personnel Resource Committee

- Prepare students and new professionals for the personal and professional risksand benefits of public advocacy through classroom materials and mentoring opportunities.

- Develop a teaching format that utilizes reflection, introspection and critical analysis in professional development through meaningful mentorship and supervision.

- Develop social justice and advocacy curriculum requirements for community agencies that agree to take students for academic practicum experiences.

\section{Conclusion}

Within the social work and counseling professions, there have been many initiatives and policy statements that strive to eliminate human rights violations and promote equality. The social work Standards for Cultural Competence, the Counseling Advocacy, LGBTQ, and Multicultural Competencies, and the UDHR, each highlight the scope of existing discrimination and draw attention to these issues on the national and international stage.

However, the intricate nature of national, state, and local government has created institutional discrimination that is so deeply engrained within our society that professional standards and documents and United Nations Conventions and Declarations are not enough. That is not to say that as professionals we should lessen our resolve to empower our clients and advocate for the eradication of human rights violations within our communities. Indeed, by striving to follow these documents and implement professional principles through a framework of "thinking globally, acting locally" we can identify areas in our own practice and communities and implement advocacy and empowerment-based solutions to protect and support every human being and his/her right to freedom.

Contact information/Correspondence:

Jessica Barrett, MSW

Email: jessica.a.ebert@gmail.com

Jessica Barrett, MSW, is a graduate from Millersville University and the coordinator of the Multicultural Social Justice Leadership Development Academy. 


\section{References}

American Counseling Association (2005). Code of ethics. Retrieved from http://www.counseling.org/Resources/CodeofEthics/TP/HOME/CT2.aspx.

Arredondo, P., Toporek, R., Brown, S., \& Jones, J. (1996). Operationalization of the multicultural counseling competencies. Journal of Multicultural Counseling and Development, 24(1), 42-78.

Curren, R. (2009). Education as a social right in a diverse society. Journal of Philosophy of Education, 1, 45-56. doi: 10.1111/j.1467-9752.2008.00663.x

Darder, A. (2007). Radicalizing the immigrant debate in the United States: A call for open borders and global human rights. New Political Science, 3, 369-384.

Gorski, P.C. (2010). Understanding multicultural curriculum transformation. Retrieved from http://www.edchange.org/multicultural/curriculum/concept.html.

Lord, J. E.,\& Stein, M. A. (2008). The domestic incorporation of human rights law and the United Nations Convention on the Rights of Persons with Disabilities. Washington Law Review 83(4), 449-479.

National Association of Social Workers [NASW] (1999). Code of ethics of the National Association of Social Workers. Retrieved from www.socialworkers.org/pubs/code/default.asp.

National Association of Social Workers [NASW] (2007). Indicators for the achievement of NASW standards for cultural competence in social work practice. Retrieved from http://www.naswdc.org/practice/standards/NASWCulturalStandardsIndicators2006.pdf.

United Nations (1951). Convention relating to the status of refugees and stateless persons. Retrieved from http://www2.ohchr.org/english/law/stateless.htm.

United Nations (1966a). International covenant on civil and political rights. Retrieved from http://daccess-dds-ny.un.org/doc/RESOLUTION/GEN/NR0/005/03/IMG/NR000503.pdf.

United Nations (1966b). International covenant on economic, social and cultural rights. Retrieved from http://daccess-ddsny.un.org/doc/RESOLUTION/GEN/NR0/005/03/IMG/NR000503.pdf.

United Nations (1979). Convention on the elimination of all forms of discrimination against women. Retrieved from www.un.org/daw.

United Nations. (1985). Declaration on the human rights of individuals who are not nationals of the country in which they live. Retrieved from http://www.un.org/documents/ga/res/40/a40r144.htm. 
United Nations (1990). Convention on the rights of the child. Retrieved on February 11, 2010 from http://www2.ohchr.org/english/law/crc.htm.

United Nations [UN] (2008). Convention on the rights of persons with disabilities. Retrieved from http://www.un.org/disabilities/

Zeigler, S. L., \& Stewart, K. B. (2009). Positioning women's rights within asylum policy a feminist analysis of political persecution. Frontiers (30)2. 